\title{
Nine successful Projects: why we Cannot Draw Lessons from our Own Experience
}

\author{
Elena A. Lenskaya* \\ Moscow School of Social and Economic Sciences \\ 2 building, 82 Vernadskogo, Moscow, 119571, Russia
}

Received 14.09.2014, received in revised form 16.10.2014, accepted 19.11.2014

While Russian community is getting tired of never ending reforms that do not seem to lead to any positive consequences but are always implemented at a country-wide scale, a number of very successful regional or local innovations have not been noticed or have even been neglected, although their outcomes have been visible and impressive. In this article we shall look at the most successful international projects which were either launched in Krasnoyarsk or in which Krasnoyarsk teachers have successfully participated in order to find out why most of the projects have eventually been discontinued and why a few of them have survived. The reason we call these projects successful is that at a certain stage they have been positively assessed by regional and federal authorities and foreign experts, and that they were highly appreciated in the professional community.

Keywords: educational project, Innovation in Education.

Research area: pedagogy, psychology.

In one of his recent articles Jal Mehta from Harvard University described four pathways of education development [1].

- The first pathway is borrowing from international experience. We all know a number of more or less successful attempts to learn from other countries reforms. Several years ago Germany made a special effort to improve PISA results of their students by learning from Finland, the winner of PISA-2000 and 2003.

- The second pathway is learning from the country's own experience (projects, pilots, regional reforms) Jal Mehta suggests that if US education leaders would consider gradual replacement of outdated elements of the system with those that have proven to be more efficient at a local level, the attitude to changes would be much more positive and the results of interventions would be much more visible. He regrets, however, that this pathway is not explored enough in the USA.

- The third pathway is changing education within the context of much broader social endeavours. The example he gives is "The Youth of Harlem" project in which

(C) Siberian Federal University. All rights reserved

* Corresponding author E-mail address: lenskaya@universitas.ru 
partners from different social agencies worked together towards a common goal, that is socialization of the delinquent young population of Harlem.

- The fourth pathway is the change that occurs in the context of full technological reconstruction. Education no longer occurs in schools only. Teachers get new roles, they are no longer providers of information, they are facilitators of the quest for knowledge.[1]

While Russia has borrowed quite a few strategies and policies from abroad, it has hardly explored any of the other three pathways. The second pathway could be very promising: while Russian community is getting tired of never ending reforms that do not seem to lead to any positive consequences but are always implemented at a country-wide scale, a number of very successful regional or local innovations have not been noticed or have even been neglected, although their outcomes have been visible and impressive. In a country as big as ours universal approaches do not work: the contexts are different, the values vary from one ethnic culture to another, the level of understanding priorities varies significantly from region to region and the only possible approach is to proceed from individual contexts and to try to disseminate successful innovations step by step and only to those who support them.

In this article we shall look at the most successful international projects which were either launched in Krasnoyarsk or in which Krasnoyarsk teachers have successfully participated in order to find out why most of the projects have eventually been discontinued and why a few of them have survived. The reason we call these projects successful is that at a certain stage they have been positively assessed by regional and federal authorities and foreign experts, and that they were highly appreciated in the professional community. These are the projects we have selected:

- KINSET, a project launched in Krasnoyarsk, which introduced a new teacher-centred highly interactive model of in-service teacher training.

- SPEX/UNEX project launched in St. Petersburg with a purpose to produce an external standardized municipal schoolleaving exam in English. Since the exam was a big success in the city, it was used as a prototype for a new unified federal exam to replace the former school leaving and university entry exams in Russia. Krasnoyarsk was chosen as a training centre for future examiners (markers, interviewers, administrators) in the Siberian part of Russia.

- New Millennium English, a federal project which had two goals. One was to produce a new set of English language textbooks for schools which would be competitive in the international textbook market and another was to train a team of school teachers to become textbook writers. Krasnoyarsk was represented by several members of the team.

- PRESET, a project originally launched in Tula. The goal of the project was to combat the shortage of English language teachers by launching a modern training program in junior pedagogical colleges. When Krasnoyarsk joined the project, it quickly became the project centre, and several new colleges were launched to deal with the shortage of teachers in the region and to train new high quality teachers of English language.

- School governing bodies, a project with a goal to introduce public governance within the school system. Krasnoyarsk launched the first pilot, the results were analysed 
at the federal level, new legislation was produced and the Ministry recommended that every school had a governing board. Krasnoyarsk people played an important role in drafting and refining the legislation, producing training manuals for governors etc.

\section{- Prevention of addictive behaviour,} a project launched and implemented in Krasnoyarsk with a goal to design a program and to train primary school teachers to run leadership training activities to prevent addictive behaviour of teenagers. The project was also implemented in Dundee (UK) and its success in Russia and abroad was so obvious that the RF Ministry of Education has circulated a letter recommending all schools to go through the training for similar programs.

- North Caucasus Education Initiative, a complex project with a purpose to support education in the North Caucasus. One of its components was devoted to promoting multicultural, diversityrespectful school ethos and Krasnoyarsk team participated as trainers. The project was conceptualized at the federal level, but implemented regionally in 4 and later in 3 more regions of the North Caucasus.

- BRIDGE, a project promoting University partnerships between Russia and UK leading to mutually recognized dual degrees. Krasnoyarsk Universities took active part in the project, and one of them was recognized among the best University partners.

\section{- Civic education (Citizenship} education), several projects devoted to civic education in secondary schools of Russia. Krasnoyarsk scholars played the leader role in all of those by designing and piloting the teacher training curriculum, designing new teaching materials, producing textbooks for future teachers.

We then decided to look at factors which contributed to sustainability of the above described projects or led to discontinuation of some of them. They are analysed in the Table 1 below.

The table clearly demonstrates that most projects, successful as they were for a certain period of time, were eventually discontinued. There are a few "survivors", but one can observe that in the course of years they were either downsized, distorted or seriously challenged.

If we look at the factors that seem to contribute to sustainability of projects these seem to be as follows:

- Federal support through appropriate legal acts and regulations, through recognition in strategic plans, through allocation of state funding and through appointing officials responsible for dissemination;

- Professional community support, support at the local level;

- Value for money, low costs of support;

- Stable leadership, high status of leaders, leadership succession planning;

- Constant feedback from key stakeholders

- Appropriate documentation of the project for dissemination purposes

Hardly any projects analysed in this article had all the necessary pre-requisites for sustainability. Interestingly, all of them were discussed and at some stage approved at the federal level, but there is no official entity in the Ministry departments responsible for appraisal and dissemination of successful innovations. Therefore, the destiny of project endeavours was left to the discretion of individual officers who usually made no effort to mobilize the appropriate support. Only one project, Prevention of Addictive Behaviour, was lucky enough to get 


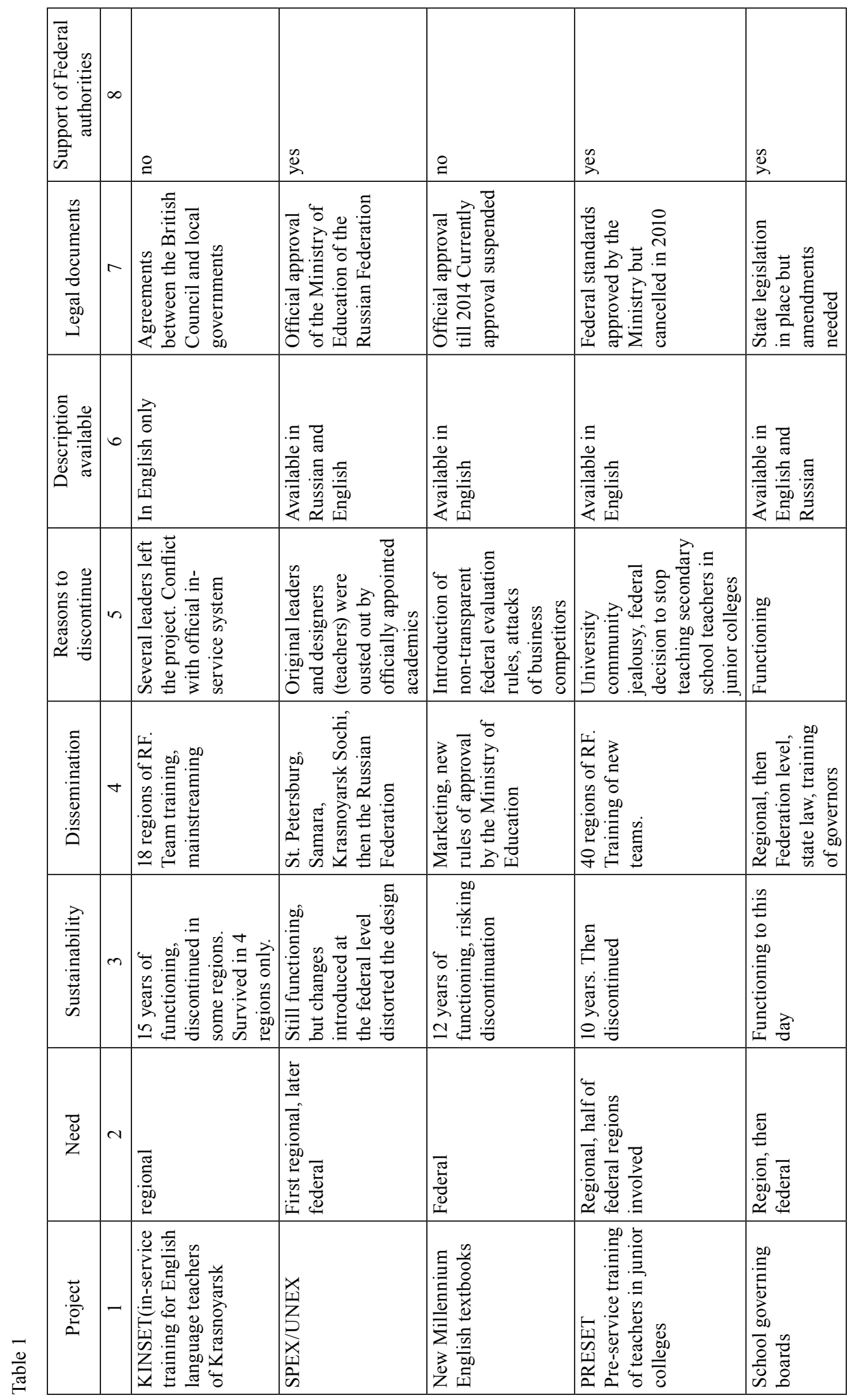




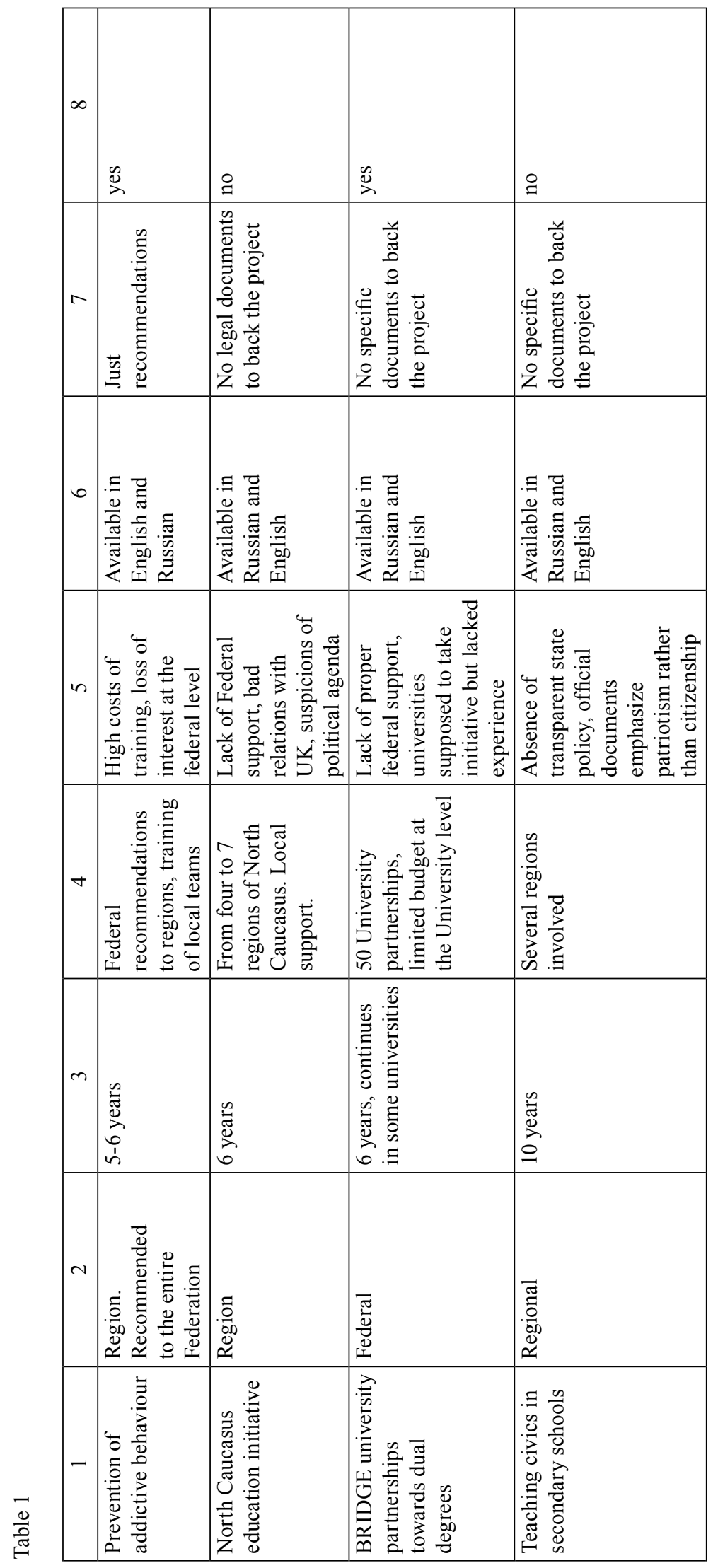


Table 2

\begin{tabular}{|l|l|}
\hline Factors originating at the federal or regional level & \multicolumn{1}{|c|}{ Factors originating at the project team level } \\
\hline The change of federal or regional priorities & Leaders and team members leaving the project \\
\hline $\begin{array}{l}\text { Reduction of the project scope at a stage of } \\
\text { mainstreaming }\end{array}$ & $\begin{array}{l}\text { Leaders not feeling competent to work at a higher } \\
\text { level }\end{array}$ \\
\hline Lack of appropriate legislation & Lack of clearly written project documentation \\
\hline $\begin{array}{l}\text { Contradictions between the current state police and } \\
\text { project goals }\end{array}$ & $\begin{array}{l}\text { Competing with the system instead of cooperating } \\
\text { with it }\end{array}$ \\
\hline Lack of officials responsible for project dissemination & $\begin{array}{l}\text { Lack of dialogue with stakeholders, neglecting some } \\
\text { of them }\end{array}$ \\
\hline
\end{tabular}

a good promoter in the Ministry, but the interest did not last long. Some support was provided by the Ministry letter circulated through all regional administrations, but there was no follow up and no attempts were made to find out whether the local administrations used the recommendations appropriately.

If we now look at the factors negatively influencing sustainability, we may distinguish between federal or regional barriers and factors that come from the project team:

Traditionally people tend to blame the authorities for not supporting projects well enough. Indeed, Ministry officials are very slow to introduce even minor changes into legislation to give the green light to a project; they often are hesitant to change the outdated practice. In case of KINSET, for instance, some rules existing in local in-service training institutions had to be reconsidered to accommodate a much more interactive programme, yet the authorities preferred to squeeze the programme into the prescribed format thus sacrificing a lot of its essential elements. Yet, as we can see, external obstacles are not the only reason for deaths of worthwhile projects.

Quite a few projects mentioned in Table 1 have suffered for internal reasons: some of the key leaders have left the project which is only natural when a project lasts for more than five years. However, most teams did not consider succession planning in advance. In case of SPEX we had a team of highly committed leaders, who however did not have the status high enough in the professional community. In Russia one can be considered to be a high quality professional only if one has an academic degree. SPEX leaders were school teachers who have gone through several rounds of intensive training in Cambridge exam syndicate, yet the Ministry chose to substitute them with some doctoral degree holders from Moscow State University who had had no training in test design whatsoever, did not believe in external testing and eventually made several severe mistakes which the trained people would have never made. Yet they had the needed status and that was what counted.

In a number of cases the project teams who have been sponsored by foreign agencies never managed to produce good project documentation in Russian. No matter how many times educational leaders of new regions were requesting KINSET description in Russian, it has never been produced, therefore causing the dissemination into regions to fail. In some cases the project teams who have designed an innovation were beginning to compete with all other teams working in the field instead of trying to cooperate with most of them. Such strategy was particularly counterproductive when the team was trying to challenge 
the existing state system- at this or that stage, sooner rather than later the system backfired at them. Some local KINSET teams did not last long for this reason.

If we now look at pre-requisites of a sustainable project these seem to be:

- a federally recognized leader having a high status in the professional community practicing distributed leadership in the project team;

- project headquarters and informative easily found web-site;

- regular publications interesting to the professional community;

- opportunity and appropriate channel to initiate new legislation;

- appropriate legal status and legislation;

- good training resources;

- high status authorities taking responsibility for promoting the project.

Some researchers argue that the project leader is directly responsible for making the project sustainable. Therefore, the leader should:

- demonstrate that the project contributes to the competitiveness of an organization or a system to win the support of the officials;

- inform the community and the authorities through press-releases, conferences, publications, exhibitions, workshops, brochures and websites using clear language free of sophisticated professional terminology ;

- develop partnerships at all levels of project management, to convert potential competitors by making them partners.

The social sector institutions and NGOs all over the world make intensive contributions into promotion of innovation, but seem to have less enthusiasm for mastering the skills of transplanting successful innovations to other needy locales.
Dissemination takes a distinct, sophisticated skill set, and successful dissemination is a process of customizing the program to new circumstances, not replicating. To replicate is "to produce an identical version, repeatedly". In several of the above mentioned projects dissemination was less successful because the main team insisted on copying everything that they have done, ignoring the context of a new location. Such mistakes were made in SPEX and particularly in the North Caucasus initiative. Customizing also meant that we had to identify barriers to adoption at potential new sites.

As Chris Fabian and Robert Fabricant argue in their article The Ethics of Innovation:

- "Customizers must become informed about their innovation's operating details and be recognized as people with groundlevel knowledge;

- Customizers must learn about specific local conditions, welcome diverse scenarios, and develop a flexible repertoire of solutions for local needs and possibilities;

- Customizers must devote substantial time to their effort, including traveling to sites one by one and inventing ways for successful adopters of a social service to pollinate places that are undecided;

- Customizers must identify barriers to adoption and sympathize with people's psychological mind-sets that prevent new ideas from taking root;

- Customizers need solid evidence about their innovation's worth: the value of the benefits, the singularity of their program for securing those benefits, and the leveraging of human and financial resources necessary to achieve success;

- Customizers must find at least one strategically positioned person at each site to serve as their champion; 
- Customizers must have timely control of seed money that can help budding programs launch pilot efforts while enthusiasm is high;

- Customizers must cede credit for successes to others and get out of the way as soon as programs are able to sustain themselves"[2]

Another lesson we can learn from other countries is about organizing financial support for disseminating innovations. The word "innovation" is probably mentioned more often in Russian social sector than any other term or word. Education in particular is the area where everyone is expected to become innovative. A real innovation, however, is not easy to customize and those who go for it have a right to expect a certain degree of financial support either from the state or from the professional community. Yet there are no venture funds in social sector in Russia, nor other means of financial support for disseminating new projects and innovations. We have looked at the means of support that exist in other countries which could be replicated here:

- In most Western countries there are grants for exploring promising ideas and projects. These grants are either provided by Universities or by special foundations such as UnLtd UK.

- In many European countries local authorities can issue small grants to mobilize volunteers to pilot innovations.

- For bigger projects and innovations countries establish challenge funds like Singapore Prime Minister's Enterprise Fund, or the UK's Invest to Save Budget.

- Once a major dissemination or customization problem is identified, countries launch competitions to identify the best way of resolving the problem. The winner usually gets a prize.
- Business incubators often take up dissemination problems.

- Social sector NGOs set up venture funds and are often commissioned to disseminate particular project outcomes.

- Networks that disseminate good ideas may often get financial support from the state.

- NGOs get vouchers to purchase ideas for dissemination from Universities.

- Business companies that have their own resources often ask their shareholders to vote for the best idea to be disseminated.

- The state sometimes commissions state -private partnerships to address a particular dissemination problem.

- A contract may be signed directly with the innovation author for them to take care of its dissemination.

- At a broader scale tenders are organized towards specific social outcomes that should be achieved through the project results dissemination.

Besides providing finance, states may play other roles in disseminating innovations. The following strategies are widespread:

- Distributed diffusion as a part of state policy. NGOs are recruited to disseminate a particular policy of positive behaviour through disseminating materials with a common brand and clearly formulated goals. An example is SKIP program in New Zealand (Strategies with Kids / Information for Parents).

- Dissemination through setting new norms and regulations. New players join the community of innovators through following particular rules and meeting certain criteria.

- Setting interim markets for new products: thus new healthy food has been 
promoted in UK by way of abolishing potentially harmful products.

- Disseminating best practices through awards for dissemination (Beacon Awards in the UK).

- Dissemination of best practices on a global scale (The World Bank etc.).

- Changing standards (a good example is Russian SPEX).

Some states chose a policy of mandating dissemination; then local agencies are coerced to follow best practices. Others, however, prefer a more subtle social approach: agencies are empowered to benefit from a particular innovation, the staff is trained, the context is carefully considered and, as a consequence, they embrace the innovation from the very start. If we compare the two policies we can see pros and cons of each approach

Analysing the difference between the two approaches, we can clearly see yet another reason why many innovations die as soon as foreign partners are no longer involved. The preferred Russian way of disseminating innovations is the mandatory one. The current reform in Moscow where schools and kindergartens are merged into huge complexes without proper consideration of contexts,without proper planning, without support of key stakeholders and by way of dividing school community into winners and losers is a good example of such a startegy. Our foreign partners usually prefer a social approach. If we look at what happened in SPEX, we can see that our British partners emphasised empowering of school teachers as key stakeholders, encouraged peer-to-peer learning and developed a community of equal partners, all of whom were ardent supporters of the new exam system. When the Ministry intervened, they immediately brought in some academic gurus supposed to become the agents of change. But agents of change cannot be appointed: a heavy risk is taken when appointing somebody to become an agent for somebody else's project. The person may not understand the innovation they are promoting or even have a negative attitude to it, they would not show while talking to the Ministry officials.This is exactly what happened: SPEX exam was very quickly disseminated to the country level but in the process of "adaptation" it became a non-valid and unreliable assessment tool.

In this article we tackled only a few cases of innovative projects in education. But even this small sample shows that state policy for

\begin{tabular}{|l|l|l|}
\hline Factors influencing dissemination & \multicolumn{1}{|c|}{ Mandatory approach } & \multicolumn{1}{|c|}{ Social (empowering) approach } \\
\hline Goal & Implementation of a new practice & $\begin{array}{l}\text { Professional development and } \\
\text { education nedded for customization } \\
\text { of a new practice within a new } \\
\text { context }\end{array}$ \\
\hline Educational staff and their context & $\begin{array}{l}\text { Staff is divided into three } \\
\text { categories: innovators, early or late } \\
\text { followers and underperformers }\end{array}$ & $\begin{array}{l}\text { Consideration is given to a } \\
\text { particular context. Administrative } \\
\text { support and resources are provided } \\
\text { to encourage peer-to-peer learning }\end{array}$ \\
\hline $\begin{array}{l}\text { Innovation nature (standards, } \\
\text { program, practice) }\end{array}$ & $\begin{array}{l}\text { Accent on gains achieved through } \\
\text { the innovation, possibility of pilots, } \\
\text { visibility of outcomes }\end{array}$ & $\begin{array}{l}\text { Accent on adaptation to a particular } \\
\text { context, careful verification of the } \\
\text { achieved results }\end{array}$ \\
\hline Dissemination strategy & $\begin{array}{l}\text { Innovation is dissemnated through } \\
\text { agents of change, people whose } \\
\text { professional opinion is valued in } \\
\text { the community }\end{array}$ & $\begin{array}{l}\text { Innovation is disseminated through } \\
\text { peer-to-peer learning in real } \\
\text { practice }\end{array}$ \\
\hline
\end{tabular}


disseminating successful project outcomes learn from our own experience, we will lose and innovations in Russia is not consistent a very powerful resource of educational and often counter-productive. If we do not innovations.

\title{
References
}

1. Jal Mehta. Four Paths for the Future. The Future of School Reform.Education Week.files

2. Chris Fabian and Robert Fabricant. The ethics of innovation. Stanford Social Innovation Review. August, 2014.

\section{Девять успешных проектов: \\ почему мы не можем извлечь уроки}

из нашего собственного опыта

\author{
Е.А. Ленская \\ Московская высшая школа \\ сочииальных и экономических наук \\ Россия, 119571, Москва, пр. Вернадского, 82, корп. 2
}

\begin{abstract}
В то время как российское сообщество устало от никогда не заканчивающихся реформ, которые, как кажется, не приведут к положстельным последствиям, но всегда реализуются в масштабе всей страны, ряд очень успешных региональных или местных инноваций не были замечены или были заброшены, хотя они дали впечатляющие результаты. В этой статье мы рассмотрим наиболее успешные международные проекты, которые были либо запущены в Красноярске или в которых принимали участие красноярские учителя для того, чтобы выяснить, почему большинство из этих проектов в итоге были прекращены, а некоторые из них выжили. Причина, почему мы называем эти проекты успешными, в том, что на определенном этапе они были положительно оценень региональными и федеральными органами власти и иностранными экспертами и высоко оиенены в профессиональном сообществе.
\end{abstract}

Ключевые слова: образовательный проект, инновачии в образовании.

Научная специальность: 13.00.00 - педагогические науки, 19.00.00-nсихологические науки. 